\title{
Bibliometric analysis of Ghana publications in the Science Citation Index Expanded
}

\author{
Peter Osei Boamah ${ }^{1} \&$ Yuh-Shan $\mathrm{Ho}^{2 *}$ \\ 1. Department of Ecological Agriculture, Bolgatanga Polytechnic, Bolgatanga, Ghana; pierrodecota@hotmail.com \\ 2. Trend Research Centre, Asia University, Taichung 41354, Taiwan; ysho@asia.edu.tw \\ * Correspondence
}

Received 08-VIII-2017. Corrected 26-X-2017. Accepted 22-XI-2017.

\begin{abstract}
Ghana is a West African country for which apparently there are limited scientometric studies. The objective of this study was to analyze the Ghanaian contribution to knowledge captured in the Thomson Reuters Science Citation Index Expanded (SCI-EXPANDED) database from 1936 - 2016. The following data were analyzed: document type, the language of publication, publication trend, Web of Science Subject Categories, Journals, international collaboration, institutions, authors, and highly cited articles. Indicators such as the total number of articles, first author articles, and corresponding author articles were applied to compare publication performance for collaborative countries and institutions. Also, number of single institute articles: number of nationally collaborative articles: number of internationally collaborative articles ( $\mathrm{S}: \mathrm{N}: \mathrm{I})$ were also used to compare publication characteristics of institutions in Ghana. Results showed that publication trend increased from 1998 to 2015, with researches focusing on health and medicine. PLoS One was the top productive journal, and the most collaborative country for Ghana articles was the USA. Contributions from the University of Ghana were ranked the top one institution for Ghana articles, and higher citation papers were found in international collaborations. In conclusion, the contribution to knowledge of Ghanaian authors is massive in the areas of public, environmental and occupational health and tropical medicine but the impact factor is higher for immunology, infectious diseases, and microbiology articles. Therefore, Ghanaian authors are encouraged to publish more articles in high impact factor journals with Thomson Reuters Scientific indexing in order to have their researches recognized by the existing international databases. Rev. Biol. Trop. 66(1): 106-121. Epub 2018 March 01.
\end{abstract}

Key words: Ghana; SCI-EXPANDED; Web of Science; research trends; collaborations.

Science Citation Index (SCI) was known in the science community in 1955, and it is currently the cutting-edge tool to facilitate the dissemination and retrieval of scientific literature (Garfield, 2006). The SCI's multidisciplinary catalogue is to achieve two objectives: i) to identify what each scientist have published, and ii) where and how often the papers by the scientist are cited (Garfield, 2007). For this reason, the author-based part in SCI journals is divided into the Source Author Index and the citation index. By inference, one can also determine what each institution and country has published, and how often their papers are cited. Web of Science (WoS) which is the
SCI-EXPANDED's electronic version can link the source author index and the citation index, and this way, author's publication can be listed by chronology, by the journal, or by citation frequency using WoS. Furthermore, it is possible to search for scientists who have published over a given period of years using the mentioned tool (Garfield, 2009). Based on the above realization, scientists have embarked on bibliometric analysis to understand the nature and complexity of research activities.

Bibliometric analysis is therefore defined as the quantitative study of science, communication in science, and science policy (Sam, 2008; Milojević \& Leydesdorff, 2013). It has 
been employed universally for quantification and assessment of the research output of researchers, research institution, academic institutions and countries (Aswathy \& Gopikuttan, 2013; Noruzi \& Abdekhoda, 2014). Generally, bibliometric analysis results are used for ranking, awarding, budgeting, and defining research priorities (Fakhree \& Jouyban, 2011). Intellectually, publications are often regarded as those that the writers have in its scholastic, or the intellectual society and their publications are managed by renowned bodies with academic ambitions and task (Alemna, 2016). It additionally mentions that learned publications do not only offer research results thereby moving forward new facts, but their contents are subjected to careful inquiry by professionals in a given field.

Recently, peer-reviewed journals using Thomson Reuters Scientific indexing services have since become accepted as definitive evidence of research endeavors of scientists all over the world (Nwagwu \& Egbon, 2011). The authors mentioned that the position of science in Africa has always been queried. They posed the following questions in their paper: i) Do scientists in Africa do research?, ii) Where and in what journals are their researches published?, and iii) What is the quality of the journals where these publications appear? Frankly, responding to the above queries require the availability of detailed evidence of research from the country in question. On the other hand, local databases infrastructures to give this picture do not exist, and current international databases are also unfair in the source selection processes. They generally leave out a lot of research outputs of researchers from the developing regions (Nwagwu \& Egbon, 2011). This has gingered researchers from Africa to publish in journals with Thomson Reuters Scientific indexing services, in order to have their researches recognized by the existing international databases, and this has been executed perfectly well via research collaboration.

The whole of Africa's research collaboration pattern, both regarding countries and cities, has been distinguished into three separate scientific regions, namely Northern, Western, and Southern-Eastern (Toivanen \& Ponomariov, 2011). For comparison purpose, Africa's contribution to the worldwide research literature has been computed (Tijssen, 2007). The scientific production component in the Southern Africa Development Community (SADC) was dealt with in this literature (Pouris, 2010). It was found in the literature that South Africa is responsible for $79 \%$ of the regional production (Pouris \& Pouris, 2009). They reported the results of an effort to calculate scientometric indicators-research publications and patentsfor the African Continent, compared them with those of other regions and discussed their implications. Collaboration ties in Central Africa's scientific output revealed that colonial and cultural ties play a major role in the international collaboration (Boshoff, 2009). Further research dealt with collaboration among the SADC countries as well as with the rest of Africa. It was concluded that South Africa acted as the political North, i.e., it dominated the regional scientific research (Boshoff, 2010).

Latest research works on bibliometric studies in Ghana include: Research focus and trends in nuclear science and technology in Ghana: A bibliometric study based on the INIS database (Agyeman \& Bilson, 2015); a scientometric analysis of research performance of Ghanaian polytechnics (Lomatey, Abledu, Baayel, Akussah, \& Botchway, 2016); research collaboration in Ghana: patterns, motives and roles (Owusu-Nimo \& Boshoff, 2017). However, among these bibliometric studies presented so far, there is no comprehensive bibliometric analysis of Ghana publications in the Science Citation Index Expanded (SCI-EXPANDED) from 1936-2015. This research will, therefore, provide the following: names of authors, title, year of publication, source journals publishing the articles, contact address, and each year citation times for every publication in SCI-EXPANDED.

\section{MATERIALS AND METHODS}

Science Citation Index Expanded (SCIEXPANDED) of Web of Science Core 
Collection of Thomson Reuters was used to collect the bibliographic data (Data last updated: July12th, 2016). An advanced search was conducted for documents with the phrase "Ghana" in the country field. Initially, 9364 publications were identified, and these documents were published between 1958 and 2015. Document information included names of authors, title, year of publication, source journals publishing the articles, contact address, and each year citation times for every publication were downloaded into Microsoft Excel 2013, and additional coding was manually performed for origin country and institute of the collaborators, and impact factors of the publishing journals (Li \& Ho, 2008). Besides, the reported impact factor $\left(I F_{2015}\right)$ of each journal was obtained from the 2015 Journal Citation Report (JCR). The total number of times a document cited from the Web of Science Core Collection since its publication to the end of 2015 was recorded as $T C_{2015}$ (Chuang, Wang, \& Ho, 2011; Wang, Fu, \& Ho, 2011). Likewise, $C_{2015}$, the total number of citations of a paper in 2015 only (Ho, 2012) were employed to characterize Ghana publications. Also, the citations per total publications $(T P)$ since publication $\left(C P P_{2015}=\right.$ $T C_{2015} / T P$ ), was also used (Ho \& Ho, 2015). Articles originating from England, Scotland, Northern Ireland, and Wales were reclassified as originating from the United Kingdom (UK). Affiliations in Hong Kong before 1997 were included in the China category, but as a separate region for consistency. Affiliations in Federal Republic of Germany (Fed Rep Ger), West Germany, Germany Democratic Republic and East Germany were checked to be in Germany (Ho, 2012). Affiliations in People's Republic of the Congo (Congo People Rep) and Republic of the Congo (Rep Congo) were checked to be in Republic of the Congo (Congo). Affiliations in Zaire were checked to be in Democratic Republic of the Congo (Dem Rep Congo) (Chuang, Chuang, Ho, \& Ho, 2011). Affiliations in UKSSR were checked to be in Ukraine. Affiliations in Czechoslovakia were checked to be in Czech Republic (Czech
Republic) (Ho, 2013). Affiliations in Greenland were checked to be in Denmark.

\section{RESULTS AND DISCUSSION}

Document type and language of publication: The distribution of the document type and language of publications identified by WoS were analyzed. Comparison of document types and their $T C_{\text {year }}$ and $C P P$ year has been reported (Chuang, Olaiya, \& Ho, 2012). A total of 9364 Ghana publications with 13 document types in the SCI-EXPANDED from 1958 to 2015 were found. Document type of review had the highest $C P P_{2015}$ of 23 followed by proceedings paper with $C P P_{2015}$ of 16. Article (7 375) was the most-frequently used document type comprising $79 \%$ of the total publications, followed distantly by meeting abstracts (1112; $12 \%)$, letters $(229 ; 2.4 \%)$, editorial materials $(220 ; 2.3 \%)$, reviews $(216 ; 2.3 \%)$, proceedings papers $(181 ; 1.9 \%)$, and notes $(147 ; 1.6$ $\%)$. The others showing less significance were corrections $(28 ; 0.30 \%)$, news items $(23 ; 0.25$ $\%)$, book chapters $(6 ; 0.064 \%)$, book reviews (6; $0.064 \%)$, discussion $(5 ; 0.053 \%)$, and reprints $(3 ; 0.032 \%)$. Similar results can also be found in tropical countries in Central America, for example, Costa Rica (Monge-Nájera \& Ho, 2012) and Panama (Monge-Nájera \& Ho, 2015) published $79 \%$ and $82 \%$ of full-length articles of the total publications, respectively. Journal articles were used for further analysis because they represented the majority of document types that also included whole research ideas and results (Ho, Satoh, \& Lin, 2010).

The lucid dominance of full articles over other types of documents was not shocking, since Ghanaian researchers/lecturers are promoted based on number of full articles published in refereed journals and working experience. This enhances the salaries of the researchers, thus discouraging other types of work such as meeting abstracts, letters, editorial materials, reviews, proceedings papers, and notes.

An internationally collaborative review entitled "Allergic rhinitis and its impact on 
asthma (ARIA) 2008” (Bousquet et al., 2008) by 96 authors from 99 institutions in 40 countries was the most cited review with $T C_{2015}$ of 1316. This is the only one review with $T C_{2015}$ $>1000$ in Ghana. Similarly, an editorial material entitled "Malaria: current status of control, diagnosis, treatment, and a proposed agenda for research and development" (Guerin et al., 2002) by nine authors from seven institutions in six countries was the most cited editorial material with $T C_{2015}$ of 196 .

Altogether, 7375 articles were extracted from the 9364 documents for further analyses. Almost all articles were published in English (7358 articles; $99.76 \%$ of 7375 articles), 10 in French and seven in German. Nearly all Ghanaians speak English because Ghana was colonized by the British, and that is reflected in the number of papers published in English. The second reason for publishing in English was to reach a wider readership (Monge-Nájera \& Ho, 2012). French was the second largest group of publishers $(0.14 \%)$ and this was not shocking, because Ghana is surrounded by three Francophone countries such as Togo, Burkina Faso, and Ivory Coast. The third largest group was German $(0.10 \%)$, which reflects the number of Ghanaian researchers who obtain their university degrees from the Federal Republic of
Germany due to important scholarships such as DAAD and KAAD.

Publication year: In order to study publication year, total number of articles $(T P)$, number of authors $(A U)$, number of cited references $(N R)$, and their averages were captured in accordance with Ho's group publications (Ho, 2007; Wambu \& Ho, 2016). Characteristics of Ghana articles in SCI-EXPANDED from 1958 to 2015 are shown in Table 1. A total of 7375 Ghana articles were published in journals listed in SCI-EXPANDED, with an average of four authors in a publication. Total number of papers was in single digit from 1958-1971, and it rose to double digits from 1972-1995 and finally to triple digits from 1996-2015. The increase in the number of papers in SCIEXPANDED journals by Ghanaian authors could be as a result of teaching and research institutions existence in Ghana as well as the local and international financial support.

In recent years, Ho proposed a relationship between classic articles and their citations per publication $\left(C P P_{\text {year }}=T C_{\text {year }} / T P\right)$ by years $(\mathrm{Ho}$, 2013). It was also applied to highly cited publications in Taiwan (Chuang \& Ho, 2015) and publications in dance field (Ho \& Ho, 2015). Fig. 1 shows the mentioned relationships which

TABLE 1

Characteristics of articles in Web of Science, 1958-2015

\begin{tabular}{cccccccc} 
Year & $T P$ & $A U$ & $A U / T P$ & $N R$ & $N R / T P$ & $P G$ & $P G / T P$ \\
1958 & 3 & 6 & 2.0 & 12 & 4.0 & 15 & 5.0 \\
1959 & 0 & 0 & $\mathrm{~N} / \mathrm{A}$ & 0 & $\mathrm{~N} / \mathrm{A}$ & 0 & $\mathrm{~N} / \mathrm{A}$ \\
1960 & 0 & 0 & $\mathrm{~N} / \mathrm{A}$ & 0 & $\mathrm{~N} / \mathrm{A}$ & 0 & $\mathrm{~N} / \mathrm{A}$ \\
1961 & 0 & 0 & $\mathrm{~N} / \mathrm{A}$ & 0 & $\mathrm{~N} / \mathrm{A}$ & 0 & $\mathrm{~N} / \mathrm{A}$ \\
1962 & 0 & 0 & $\mathrm{~N} / \mathrm{A}$ & 0 & $\mathrm{~N} / \mathrm{A}$ & 0 & $\mathrm{~N} / \mathrm{A}$ \\
1963 & 0 & 0 & $\mathrm{~N} / \mathrm{A}$ & 0 & $\mathrm{~N} / \mathrm{A}$ & 0 & $\mathrm{~N} / \mathrm{A}$ \\
1964 & 0 & 0 & $\mathrm{~N} / \mathrm{A}$ & 0 & $\mathrm{~N} / \mathrm{A}$ & 0 & $\mathrm{~N} / \mathrm{A}$ \\
1965 & 0 & 0 & $\mathrm{~N} / \mathrm{A}$ & 0 & $\mathrm{~N} / \mathrm{A}$ & 0 & $\mathrm{~N} / \mathrm{A}$ \\
1966 & 2 & 2 & 1.0 & 15 & 7.5 & 23 & 12 \\
1967 & 1 & 1 & 1.0 & 23 & 23 & 1 & 1.0 \\
1968 & 2 & 2 & 1.0 & 11 & 5.5 & 7 & 3.5 \\
1969 & 0 & 0 & $\mathrm{~N} / \mathrm{A}$ & 0 & $\mathrm{~N} / \mathrm{A}$ & 0 & $\mathrm{~N} / \mathrm{A}$ \\
1970 & 1 & 1 & 1.0 & 7 & 7.0 & 2 & 2.0 \\
1971 & 3 & 7 & 2.3 & 40 & 13 & 18 & 6.0 \\
\hline
\end{tabular}


TABLE 1 (Continued)

\begin{tabular}{|c|c|c|c|c|c|c|c|}
\hline Year & $T P$ & $A U$ & $A U / T P$ & $N R$ & $N R / T P$ & $P G$ & $P G / T P$ \\
\hline 1972 & 11 & 18 & 1.6 & 151 & 14 & 51 & 4.6 \\
\hline 1973 & 67 & 127 & 1.9 & 805 & 12 & 477 & 7.1 \\
\hline 1974 & 80 & 154 & 1.9 & 1068 & 13 & 586 & 7.3 \\
\hline 1975 & 61 & 124 & 2.0 & 951 & 16 & 572 & 9.4 \\
\hline 1976 & 55 & 128 & 2.3 & 963 & 18 & 424 & 7.7 \\
\hline 1977 & 73 & 162 & 2.2 & 1105 & 15 & 523 & 7.2 \\
\hline 1978 & 62 & 160 & 2.6 & 820 & 13 & 455 & 7.3 \\
\hline 1979 & 56 & 141 & 2.5 & 797 & 14 & 406 & 7.3 \\
\hline 1980 & 66 & 141 & 2.1 & 900 & 14 & 508 & 7.7 \\
\hline 1981 & 59 & 152 & 2.6 & 872 & 15 & 425 & 7.2 \\
\hline 1982 & 55 & 139 & 2.5 & 747 & 14 & 432 & 7.9 \\
\hline 1983 & 39 & 94 & 2.4 & 585 & 15 & 303 & 7.8 \\
\hline 1984 & 47 & 140 & 3.0 & 752 & 16 & 304 & 6.5 \\
\hline 1985 & 65 & 188 & 2.9 & 1067 & 16 & 473 & 7.3 \\
\hline 1986 & 38 & 114 & 3.0 & 478 & 13 & 244 & 6.4 \\
\hline 1987 & 37 & 108 & 2.9 & 688 & 19 & 276 & 7.5 \\
\hline 1988 & 43 & 147 & 3.4 & 666 & 15 & 281 & 6.5 \\
\hline 1989 & 51 & 135 & 2.6 & 647 & 13 & 319 & 6.3 \\
\hline 1990 & 51 & 172 & 3.4 & 876 & 17 & 403 & 7.9 \\
\hline 1991 & 62 & 212 & 3.4 & 1170 & 19 & 490 & 7.9 \\
\hline 1992 & 88 & 241 & 2.7 & 1593 & 18 & 709 & 8.1 \\
\hline 1993 & 74 & 271 & 3.7 & 1483 & 20 & 613 & 8.3 \\
\hline 1994 & 83 & 289 & 3.5 & 1575 & 19 & 575 & 6.9 \\
\hline 1995 & 89 & 339 & 3.8 & 1389 & 16 & 627 & 7.0 \\
\hline 1996 & 122 & 426 & 3.5 & 2408 & 20 & 853 & 7.0 \\
\hline 1997 & 123 & 441 & 3.6 & 2528 & 21 & 986 & 8.0 \\
\hline 1998 & 125 & 523 & 4.2 & 2485 & 20 & 887 & 7.1 \\
\hline 1999 & 143 & 577 & 4.0 & 3346 & 23 & 1255 & 8.8 \\
\hline 2000 & 164 & 705 & 4.3 & 3610 & 22 & 1230 & 7.5 \\
\hline 2001 & 155 & 831 & 5.4 & 3632 & 23 & 1178 & 7.6 \\
\hline 2002 & 160 & 786 & 4.9 & 3769 & 24 & 1159 & 7.2 \\
\hline 2003 & 169 & 870 & 5.1 & 4159 & 25 & 1307 & 7.7 \\
\hline 2004 & 181 & 1515 & 8.4 & 4633 & 26 & 1499 & 8.3 \\
\hline 2005 & 202 & 1212 & 6.0 & 5386 & 27 & 1707 & 8.5 \\
\hline 2006 & 225 & 1405 & 6.2 & 6337 & 28 & 1961 & 8.7 \\
\hline 2007 & 269 & 1545 & 5.7 & 7346 & 27 & 2296 & 8.5 \\
\hline 2008 & 284 & 1700 & 6.0 & 8638 & 30 & 2386 & 8.4 \\
\hline 2009 & 323 & 2110 & 6.5 & 10084 & 31 & 2751 & 8.5 \\
\hline 2010 & 418 & 2752 & 6.6 & 13950 & 33 & 3780 & 9.0 \\
\hline 2011 & 415 & 2912 & 7.0 & 13174 & 32 & 3616 & 8.7 \\
\hline 2012 & 494 & 4718 & 9.6 & 18350 & 37 & 4685 & 9.5 \\
\hline 2013 & 560 & 4189 & 7.5 & 20271 & 36 & 5050 & 9.0 \\
\hline 2014 & 625 & 6171 & 9.9 & 24512 & 39 & 6281 & 10 \\
\hline 2015 & 794 & 8836 & 11 & 31774 & 40 & 8797 & 11 \\
\hline Total & 7375 & 48139 & & 212648 & & 64206 & \\
\hline Average & & & 4.0 & & 20 & & 7.5 \\
\hline
\end{tabular}

$T P$ : total number of articles; $A U$ : number of authors; $N R$ : number of cited references; $P G$ : page counts, N/A: not available. 


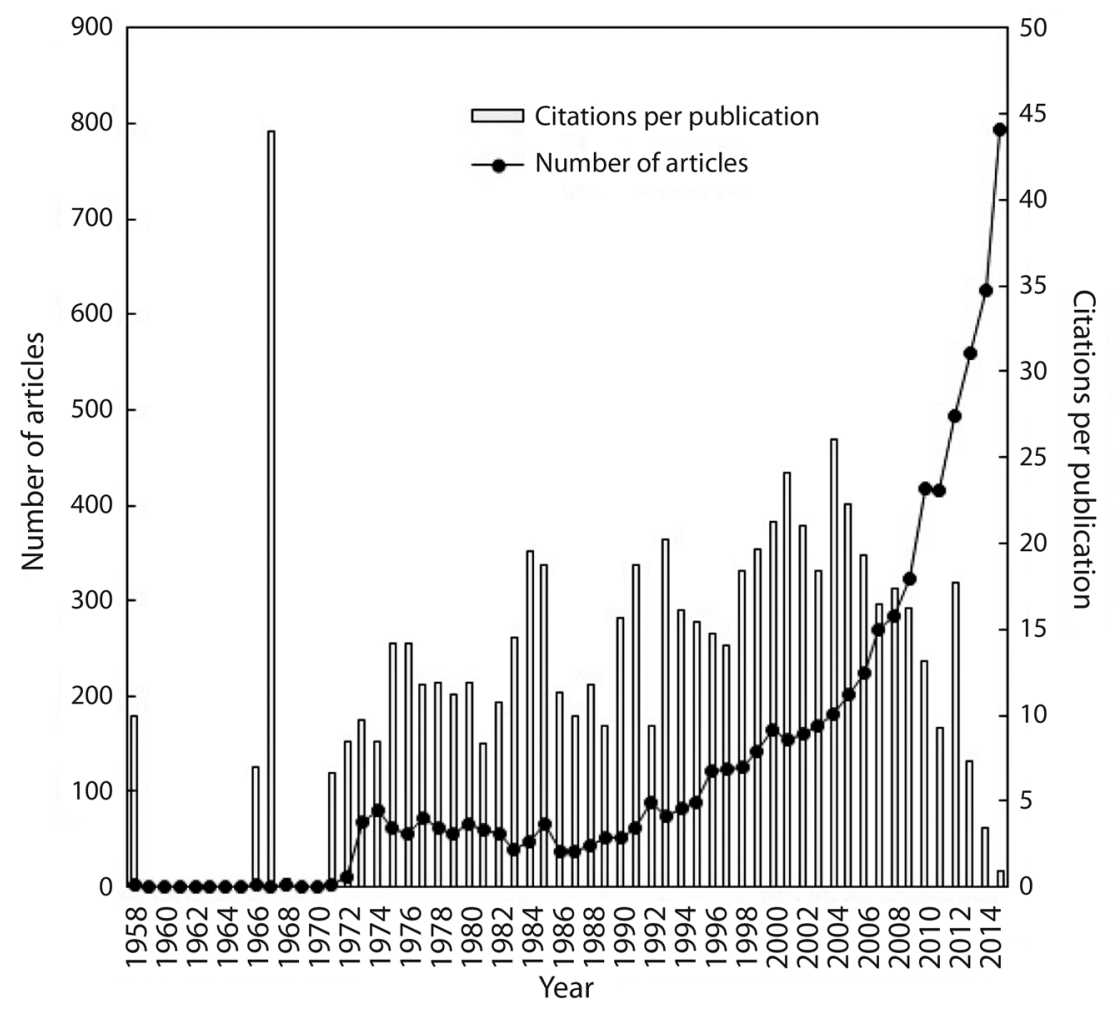

Fig. 1. Number of total articles and citations per publication.

indicate that there is no significant change in the first period from 1958 to 1972 and 1973 to 1996 , respectively. In 1958, T. W. Tinsley and co-workers from West African Cocoa Research Institute in Ghana published three earliest Ghana articles about viruses and cacao in Annals of Applied Biology (Attafuah \& Tinsley, 1958; Knight \& Tinsley, 1958; Tinsley \& Wharton, 1958). In the third period from 1997 to 2015 , publication trend increased from 123 articles to 794 articles. The significant increase in publication trend in the third period was expected, because most of the research-performing institutions in Ghana were established after the independence, and that accounted for the increase in the publication trend (OwusuNimo \& Boshoff, 2017).

The $C P P_{2015}$ for 7375 Ghana articles was 13. An extremely high $C P P_{2015}$ was found in 1967 with 44, attributed to the only one article in 1967, entitled "Tongue root position in Akan
Vowell harmony" (Stewart, 1967). This was not surprising at all because it was mentioned in the paper that the Akan (Twi-Fante) language shares with a multitude of other African languages a type of vowel harmony which is apparently found nowhere outside Africa. Also, the vowels of these languages always, it seems, fall into two harmonizing sets, one of which has relatively high and the other relatively low tongue positions, and consequently many writers have seen relative tongue height as the articulatory basis of the harmony. Furthermore, our search shows that the Akan language is studied in major universities in the United States, including Ohio University, Ohio State University, University of Wisconsin, Harvard University, Boston University, Indiana University, Michigan University, and The University of Florida, and this could have also attributed to extremely high $C P P_{2015}$ that was found in 1967. 


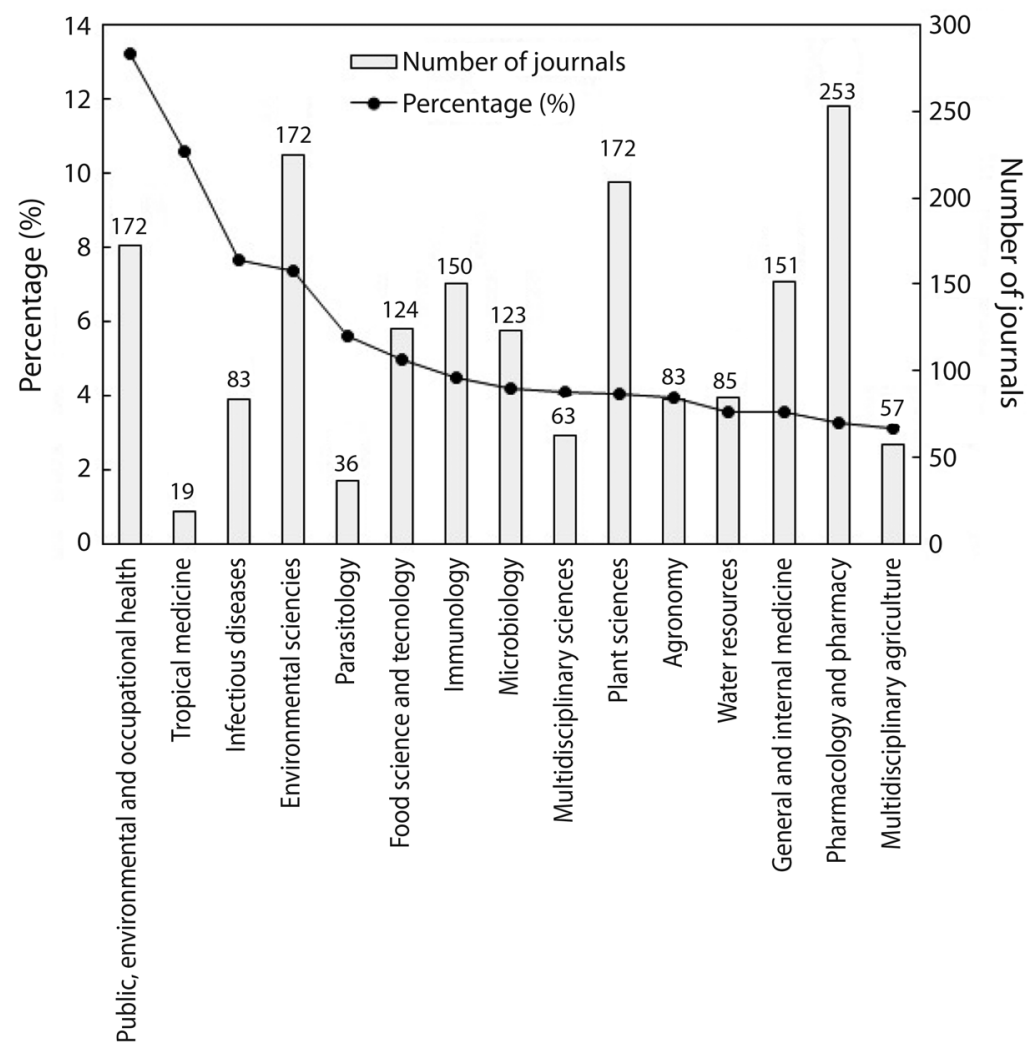

Fig. 2. Top 15 Web of Science categories of Republic of Ghana's publications.

Web of Science subject categories and journals: To study Web of Science subject categories, we followed literature which focuses on a country (Monge-Nájera \& Ho, 2012, 2015). According to Journal Citation Reports (JCR) in 2015, there were 177 Web of Science categories in SCI-EXPANDED. Ghana articles were published across 173 Web of Science categories, but no articles in categories of andrology (5 journals), microscopy (10 journals), neuroimaging (14 journals), and ocean engineering (14 journals). Fig. 2 shows top 15 productive categories and number of journals in each category. Category of public, environmental and occupation health, had the highest total articles (976) followed by tropical medicine (780) and then environmental sciences followed with 543. Authors in Ghana were active in tropical medicine in which there were only 19 journals. Similarly, tropical countries in Central America, for example, Nicaragua (Monge-Nájera \& Ho, 2017a) and Honduras (Monge-Nájera \& Ho, 2017b) also published the most articles in category of public, environmental and occupation health, but Costa Rica (Monge-Nájera \& Ho, 2012) and Panama (Monge-Nájera \& Ho, 2015) paid more attention to plant sciences.

In total, 7375 Ghana articles were published in 1917 journals in SCI-EXPANDED. Table 2 shows the distribution of articles in the top 10 journals. The value of the indicator $I F_{2015}$ for each journal was obtained from JCR for 2015. The journal with the most published articles was PLoS One which published 193 articles, $2.6 \%$ of all analyzed articles. PLoS One fell into the category of multidisciplinary sciences and had an $I F_{2015}$ of 3.057. The second position was Malaria Journal with 141 published articles (1.9\%) in Web of Science 
TABLE 2

Top 10 productive journals

\begin{tabular}{|c|c|c|c|}
\hline Journal & $T P(\%)$ & $I F_{2015}$ & Web of Science subject category \\
\hline PLoS One & $193(2.6)$ & 3.057 & multidisciplinary sciences \\
\hline Malaria Journal & $141(1.9)$ & 3.079 & $\begin{array}{l}\text { infectious diseases } \\
\text { parasitology } \\
\text { tropical medicine }\end{array}$ \\
\hline Tropical Medicine and International Health & $139(1.9)$ & 2.519 & $\begin{array}{l}\text { public, environmental and occupational health } \\
\text { tropical medicine }\end{array}$ \\
\hline $\begin{array}{l}\text { Transactions of the Royal Society of Tropical } \\
\text { Medicine and Hygiene }\end{array}$ & $106(1.4)$ & 1.631 & $\begin{array}{l}\text { public, environmental and occupational health } \\
\text { tropical medicine }\end{array}$ \\
\hline $\begin{array}{l}\text { American Journal of Tropical Medicine and } \\
\text { Hygiene }\end{array}$ & $100(1.4)$ & 2.453 & $\begin{array}{l}\text { public, environmental and occupational health } \\
\text { tropical medicine }\end{array}$ \\
\hline BMC Public Health & $82(1.1)$ & 2.209 & public, environmental and occupational health \\
\hline $\begin{array}{l}\text { International Journal of Gynecology and } \\
\text { Obstetrics }\end{array}$ & $79(1.1)$ & 1.674 & obstetrics and gynecology \\
\hline Global Health Action & $71(1.0)$ & 1.896 & public, environmental and occupational health \\
\hline East African Medical Journal & $68(0.92)$ & N/A & general and internal medicine \\
\hline Journal of Infectious Diseases & $68(0.92)$ & 6.344 & $\begin{array}{l}\text { immunology } \\
\text { infectious diseases } \\
\text { microbiology }\end{array}$ \\
\hline
\end{tabular}

categories of infectious diseases, parasitology, and tropical medicine with $I F_{2015}$ of 3.079 . It was followed by Tropical Medicine and International Health. Five of the 10 journals in Table 2 were in the Web of Science category of public, environmental and occupational health. Four journals were in category of tropical medicine. This was not surprising since most of the avid Ghanaian writers were with the health research institutions. Researchers in the medical field were able to attract funding from local and international donors, and they are required to publish their findings in SCI-EXPANDED journals with wider readership.

International collaboration: In total, 5038 Ghana articles (68\% of 7375 articles) were internationally collaborative articles with 172 countries. Table 3 shows the distribution of the top 20 collaborative countries with Ghana. The most productive countries according to the number of published articles in collaboration with Ghanaian researchers were USA and UK, but there were more published articles by Ghanaian researchers with USA researchers playing the leading role $(F P$ and $R P)$. However, percentage of articles with leading role by Ghanaian researchers is pretty low for all shown countries. It is worth noting that South Africa being an African country, was the fifth country among the top 20 collaborative countries for Ghana articles in the Science Citation Index Expanded (1958 2015) (Table 3). Among the top 20 countries only Burkina Faso shares boundary with Ghana. More collaboration with non-adjacent countries such as USA and UK than neighbouring countries can be explained with economic and social development, research and development expenditure of these countries (OwusuNimo \& Boshoff, 2017). Also, most researchers from Ghana went to American and European universities to study, and that accounted for the high collaboration with those countries (Monge-Nájera \& Ho, 2012). 
TABLE 3

Top 20 collaborative countries for Ghana articles in the Science Citation Index Expanded (1958 2015)

\begin{tabular}{lcccc}
\multicolumn{1}{c}{ Country } & $C P$ & $C P R(\%)$ & $F P R(\%)$ & $R P R(\%)$ \\
USA & 1623 & $1(22)$ & $1(12)$ & $1(12)$ \\
UK & 1383 & $2(19)$ & $2(8.7)$ & $3(9.1)$ \\
Germany & 600 & $3(8.1)$ & $3(4.6)$ & $4(2.8)$ \\
Netherlands & 467 & $4(6.3)$ & $4(2.7)$ & $9(1.8)$ \\
South Africa & 384 & $5(5.2)$ & $9(1.7)$ & $10(1.4)$ \\
Switzerland & 339 & $6(4.6)$ & $10(1.2)$ & $5(2.0)$ \\
Canada & 287 & $7(3.9)$ & $5(1.9)$ & $7(1.9)$ \\
Japan & 287 & $7(3.9)$ & $6(1.8)$ & $5(2.0)$ \\
Denmark & $9(3.9)$ & $6(1.8)$ & $12(0.94)$ \\
Kenya & 286 & $10(3.9)$ & $12(1.0)$ & $11(1.0)$ \\
Nigeria & 285 & $11(3.8)$ & $11(1.1)$ & $8(1.9)$ \\
China & 282 & $12(3.1)$ & $6(1.8)$ & $13(0.92)$ \\
France & 229 & $12(3.1)$ & $13(0.91)$ & $17(0.58)$ \\
Australia & 229 & $14(3.0)$ & $15(0.57)$ & $14(0.75)$ \\
Sweden & 220 & $14(3.0)$ & $14(0.73)$ & $20(0.33)$ \\
Tanzania & 220 & $16(2.3)$ & $20(0.34)$ & $19(0.34)$ \\
Burkina Faso & 172 & $17(2.1)$ & $19(0.35)$ & $24(0.23)$ \\
India & 155 & $18(1.9)$ & $23(0.24)$ & $15(0.63)$ \\
Italy & 138 & $19(1.8)$ & $16(0.56)$ & $16(0.61)$ \\
Belgium & 135 & $20(1.6)$ & $17(0.53)$ & \\
\hline
\end{tabular}

$C P$ : internationally collaborative articles with Ghana; $C P R(\%)$ : rank of internationally collaborative articles and percentage; $F P R(\%)$ : rank of article with first author and percentage; $R P R(\%)$ : rank of article with corresponding author and percentage.

Institutions: The national (590 articles; $8.0 \%$ of 7375 articles) and internationally collaborative articles (5038; $68 \%$ ) with Ghana were considered as the inter-institutional collaboration $(5628 ; 76 \%)$. Indicators such as total number of articles, $T P$, first author articles, $F P$, and corresponding author articles, $R P$, have been presented to evaluate publication performance (Wang, Yu, \& Ho, 2010). Furthermore, an indicator $S N I$, a proportion of single institution articles: nationally collaborative articles: internationally collaborative articles $(S: N: I)$ was applied to compare and describe institutions' publication characteristics (Ho \& Fu, 2016). Table 4 shows the top 10 institutions for Ghana articles in the Science Citation Index Expanded. Researchers affiliated to those ten institutions published $69 \%$ of all 7375 analyzed articles. University of Ghana took the first position in indicators of $T P, F P$, and $R P$. The University of Ghana is the oldest university in this country, and one of the first to have been established in West Africa; it was established in 1948 and now offers degree programmes on varied broad disciplines such as health sciences, engineering sciences, natural sciences, nuclear and allied sciences, agricultural sciences, humanities, law, business, social sciences and performing arts. During the period 1958-2015, University of Ghana published $36 \%$ of the analysed Ghana articles, $32 \%$ of the first author articles, and $31 \%$ of the corresponding author articles. The second place by $T P, F P$, and $R P$ indicators was taken by Kwame Nkrumah University of Science and Technology.

In Ghana, the proportion of $S: N: I$ was 24:8.0:68. University of Ghana's proportion of $S: N: I$ was 23:12:65. University of Science and Technology was able to conduct research independently with $S: N: I=51: 6.4: 42$. Ghana Atomic Energy Commission had more national 
TABLE 4

Top 10 institutions for Ghana articles in the Science Citation Index Expanded

\begin{tabular}{lccccccc}
\multicolumn{1}{c}{ Institute } & $T P$ & $T P R(\%)$ & $F P R(\%)$ & $R P R(\%)$ & $\% S I(S I)$ & $\% N C(N C)$ & $\% I C(I C)$ \\
University of Ghana & 2621 & $1(36)$ & $1(32)$ & $1(31)$ & $23(598)$ & $12(315)$ & $65(1708)$ \\
Kwame Nkrumah University of Science and Technology & 958 & $2(13)$ & $2(10)$ & $2(9.5)$ & $16(152)$ & $14(131)$ & $70(675)$ \\
University of Cape Coast & 415 & $3(5.6)$ & $4(6.5)$ & $3(6.8)$ & $37(152)$ & $12(51)$ & $51(211)$ \\
University of Science and Technology & 375 & $4(5.1)$ & $3(6.9)$ & $4(6.8)$ & $51(193)$ & $6.4(24)$ & $42(157)$ \\
Komfo Anokye Teaching Hospital & 273 & $5(3.7)$ & $11(1.5)$ & $14(1.3)$ & $3.3(9)$ & $12(32)$ & $85(232)$ \\
Ghana Atomic Energy Commission & 247 & $6(3.3)$ & $6(3.6)$ & $6(3.8)$ & $20(50)$ & $34(83)$ & $46(114)$ \\
Council for Scientific and Industrial Research (CSIR) & 245 & $7(3.3)$ & $5(3.8)$ & $5(4.0)$ & $29(71)$ & $21(52)$ & $50(122)$ \\
Ghana Health Service & 237 & $8(3.2)$ & $29(0.84)$ & $33(0.78)$ & $2.5(6)$ & $8(19)$ & $89(212)$ \\
Ministry of Health & 184 & $10(2.5)$ & $16(1.2)$ & $18(1.2)$ & $9.2(17)$ & $10(18)$ & $81(149)$ \\
University of Dev Studies & 184 & $10(2.5)$ & $9(1.8)$ & $9(1.8)$ & $12(22)$ & $16(30)$ & $72(132)$ \\
\hline
\end{tabular}

$T P$ : total number of articles; TPR (\%): rank of total number of articles and percentage; $F P R(\%)$ : rank of first author articles and percentage in all Ghana articles with first author information in Web of Science; $R P R(\%)$ : rank of corresponding author articles and percentage in all Ghana articles with corresponding author information in Web of Science; \% $S I(S I)$ : percentage in $T P$ in an institute and single institute articles; $\% N C(N C)$ : percentage in $T P$ in an institute and nationally collaborative articles; \%IC $(I C)$ : percentage in $T P$ in an institute and number of internationally collaborative articles.

teamwork or collaboration among different institutions with $S: N: I=20: 34: 46$. In Table 4, only University of Science and Technology $(S: N: I=51: 6.4: 42)$ had at $<50 \%$ internationally collaborative articles of its total publications. Ghana Health Service had the highest percentage of international collaboration with $S: N: I=2.5: 8.0: 89$. Our search showed that this trend was expected, because it agrees with the core functions of Ghana Health Service. The core functions of Ghana Health Service include the following: i) The analysis of national, bilateral and international policies and their application in the development of strategic plans and implementation guidelines for the Ghana Health Service in collaboration with other Divisions and implementation partners; ii) the coordination, guidance and development of short, medium and long-term plans and budgets for the Ghana Health Service's development, including the preparation of projects and programmes for local and international financing consistent with the Sector-Wide/Multi-Donor Budget Approach; and iii) the development of level specific performance indicators and contracts consistent with national, bilateral and international expectations, among others.
Authors: This section explores the distribution of articles by Ghanaian authors. Figure 3 captures number of articles and citations per publication. Internationally collaborative papers had the highest number of articles (5038) followed by the corresponding author not from Ghana (3913) and then the first author from Ghana followed with 3708 articles. The highest citations per publication (19) were registered by both first and corresponding authors not from Ghana. This was expected because most Ghanaian researchers collaborate with researchers from countries such as USA, UK, Germany, Netherlands, South Africa, Switzerland, Canada, Japan, Denmark, Kenya, Nigeria, China, France, Australia, Sweden, Tanzania, Burkina Faso, India, Italy, and Belgium. It is believed that Ghana is limited to some extent when it comes to sophisticated equipment for science and technology research. This confirms research conducted by Atuahene (2011) on the topic "Re-thinking the Missing Mission of Higher Education: An Anatomy of the Research Challenge of African Universities". He mentioned the following as the challenges which retard research in African universities: the poor research infrastructure, 


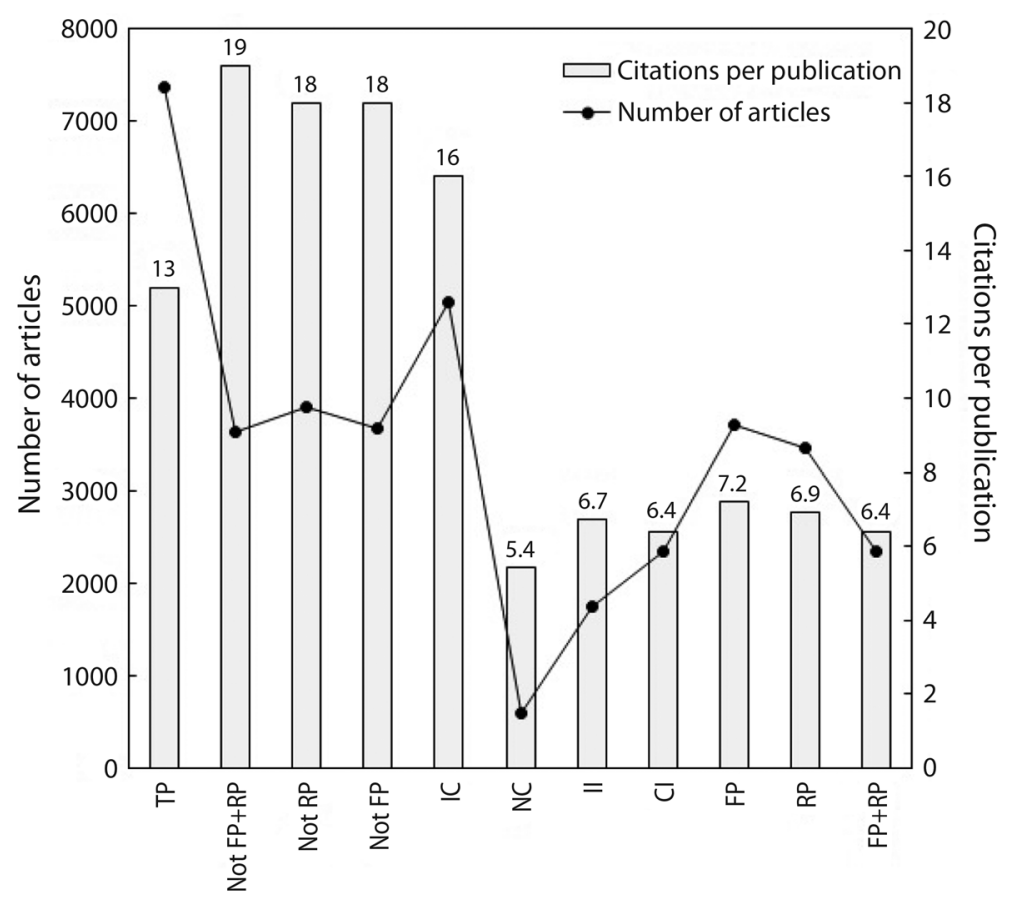

Fig. 3. Distribution of articles by Ghanaians authors. TP: total articles. Not FP+RP: both first and corresponding authors are not from Ghana. Not RP: corresponding author is not from Ghana. Not FP: first author is not from Ghana. IC: internationally collaborative papers. NC: nationally collaborative papers. II: institutional independent papers. CI: Ghana independent papers. FP: first author is from Ghana. RP: corresponding author is from Ghana. FP+RP: both first and corresponding authors are from Ghana.

limited Information and Communication Technologies (ICTs), the lack of leadership mandate and support, the lack of congenial political and academic environment in some countries, shortage and lack of faculty to pursue academic research due to heavy teaching loads and inadequate financial support. Furthermore, Table 5 listed indicators including total number of articles, number of article with first author, number of article with corresponding author and number of single author articles, for the top 11 productive authors, each with 60 or more articles. S. Owusu-Agyei, an epidemiologist with extensive experience in the design and conduct of clinical and field intervention trials from Ghana Health Service was ranked first with 125 articles, twenty-first with ten articles as the first author and twenty-second with 10 articles as corresponding author. He has been the Director of the Kintampo Health Research Centre (KHRC) since 2002. He is a part-time Lecturer in the Departments of Epidemiology and Population Health and Infectious Tropical Diseases, London School of Hygiene and Tropical Medicine (LSHTM) and a Senior Lecturer at the School of Public Health, University of Ghana, Legon. The second position was occupied by B. J. B. Nyarko, Director-General from Ghana Atomic Energy Commission with 77 articles, $32^{\text {nd }}$ with nine articles as the first author, $28^{\text {th }}$ with nine as the corresponding author. The third position was occupied by A. Hodgson from Navrongo Health Research Centre with 75 articles, $428^{\text {th }}$ position with two articles as the first author, $645^{\text {th }}$ position with one paper as the corresponding author. It was not surprising that the top three spots were occupied by prolific writers from research 
TABLE 5

Top 11 authors for Ghana articles in the Science Citation Index Expanded. Only authors with at least 60 articles

\begin{tabular}{llcccc}
\multicolumn{1}{c}{ Author } & \multicolumn{1}{c}{ Affiliation } & rank $(T P)$ & rank $(F P)$ & $\operatorname{rank}(R P)$ & rank $(S P)$ \\
S. Owusu-Agyei & Ghana Health Service, Ghana & $1(125)$ & $21(10)$ & $22(10)$ & N/A \\
B. J. B. Nyarko & Ghana Atomic Energy Commission, Ghana & $2(77)$ & $32(9)$ & $28(9)$ & N/A \\
A. Hodgson & Navrongo Health Research Centre, Ghana & $3(75)$ & $428(2)$ & $645(1)$ & N/A \\
$\begin{array}{ll}\text { F. K. Nkrumah } \\
\text { O. Adjei }\end{array}$ & University of Ghana, Ghana & $4(70)$ & $32(9)$ & $359(2)$ & N/A \\
& Kwame Nkrumah University of Science and & $5(69)$ & $169(4)$ & $228(3)$ & N/A \\
E. H. K. Akaho & Technology, Ghana & & & & \\
K. A. Koram & University of Ghana, Ghana & $6(67)$ & $59(7)$ & $79(6)$ & $130(1)$ \\
K. Awadzi & Onchocerciasis Chemotherapy Research & $8(64)$ & $1(29)$ & $3(23)$ & $130(1)$ \\
& Centre, Ghana & & & & $130(1)$ \\
B. D. Akanmori & University of Ghana, Ghana & $9(62)$ & $169(4)$ & $7(15)$ & N/A \\
S. Adjei & University of Ghana, Ghana & $10(58)$ & $787(1)$ & $645(1)$ & $130(1)$ \\
\hline
\end{tabular}

$T P$ : total number of articles; $F P$ : number of article with first author; $R P$ : number of article with corresponding author; $S P$ : number of single author articles; N/A: not available.

TABLE 6

Top 11 Ghana articles with more than 300 citations $\left(T C_{2015}>300\right)$

\begin{tabular}{|c|c|c|c|c|}
\hline $\operatorname{Rank}\left(T C_{2015}\right)$ & $\operatorname{Rank}\left(C_{2015}\right)$ & Article title & $A U$ & Reference \\
\hline $1(1849)$ & $1(897)$ & $\begin{array}{l}\text { Global and regional mortality from } 235 \text { causes of death for } \\
20 \text { age groups in } 1990 \text { and 2010: a systematic analysis for the } \\
\text { Global Burden of Disease Study } 2010\end{array}$ & 189 & Lozano et al. (2012) \\
\hline $2(1370)$ & $2(638)$ & $\begin{array}{l}\text { Disability-adjusted life years (DALYs) for } 291 \text { diseases and } \\
\text { injuries in } 21 \text { regions, 1990-2010: a systematic analysis for the } \\
\text { Global Burden of Disease Study } 2010\end{array}$ & 359 & Murray et al. (2012) \\
\hline $3(954)$ & $3(458)$ & $\begin{array}{l}\text { Years lived with disability (YLDs) for } 1160 \text { sequelae of } 289 \\
\text { diseases and injuries 1990-2010: a systematic analysis for the } \\
\text { Global Burden of Disease Study } 2010\end{array}$ & 355 & Vos et al. (2012) \\
\hline $4(864)$ & $4(415)$ & The global distribution and burden of dengue & 18 & Bhatt et al. (2013) \\
\hline $5(528)$ & $7(125)$ & $\begin{array}{l}\text { Science for managing ecosystem services: Beyond the } \\
\text { Millennium Ecosystem Assessment }\end{array}$ & 15 & Carpenter et al. (2009) \\
\hline $6(462)$ & $5(406)$ & $\begin{array}{l}\text { Global, regional, and national prevalence of overweight and } \\
\text { obesity in children and adults during 1980-2013: a systematic } \\
\text { analysis for the Global Burden of Disease Study } 2013\end{array}$ & 140 & $\mathrm{Ng}$ et al. (2014) \\
\hline $7(367)$ & $35(25)$ & $\begin{array}{l}\text { Effect of intravenous corticosteroids on death within } 14 \text { days } \\
\text { in } 10008 \text { adults with clinically significant head injury (MRC } \\
\text { CRASH trial): randomised placebo-controlled trial }\end{array}$ & 471 & Muzha et al. (2004) \\
\hline $8(327)$ & $15(49)$ & Increasing carbon storage in intact African tropical forests & 33 & Lewis et al. (2009) \\
\hline $9(318)$ & $61(18)$ & $\begin{array}{l}\text { A high-density admixture map for disease gene discovery in } \\
\text { African Americans }\end{array}$ & 32 & Smith et al. (2004) \\
\hline $10(307)$ & $529(5)$ & $\begin{array}{l}\text { Rationale for development of a synthetic vaccine against } \\
\text { plasmodium-falciparum malaria }\end{array}$ & 7 & Zavala et al. (1985) \\
\hline $11(306)$ & $14(52)$ & $\begin{array}{l}\text { First results of phase } 3 \text { trial of RTS, S/AS01 malaria vaccine in } \\
\text { African children }\end{array}$ & 142 & Agnandji et al. (2012) \\
\hline
\end{tabular}

$T C_{2015}$ : total number of times article cited from the Web of Science Core Collection since its publication to the end of 2015:

$C_{2015}$ : total number of citations of a paper in 2015 only; $A U$ : number of authors. 
based institutions and this could be due to the financial support they generally receive from both local and international donors for cuttingedge research.

Highly cited articles: This section captures Ghana articles including total number of times each article was cited from the Web of Science Core Collection since its publication to the end of $2015\left(T C_{2015}\right)$, total number of citations of a paper in 2015 only $\left(C_{2015}\right)$, and the number of authors $(A U)$. Table 6 shows the top 11 Ghana articles with more than 300 citations $\left(T C_{2015}>300\right)$. The 11 articles were all of international collaboration. Both first and corresponding authors were not from Ghana. Seven first authors were from USA, three from the UK, and one from Australia while eight corresponding authors from USA and three from the UK. The article titled "Global and regional mortality from 235 causes of death for 20 age groups in 1990 and 2010: a systematic analysis for the Global Burden of Disease Study 2010" (Lozano et al. 2012) was published in Lancet by 189 authors and was ranked first for $T C_{2015}$. The second position was occupied by the article titled "Disability-adjusted life years (DALYs) for 291 diseases and injuries in 21 regions, 1990-2010: a systematic analysis for the Global Burden of Disease Study 2010" (Murray et al., 2012) also published in Lancet by 359 authors. It is clear from Table 6 that the top three most cited articles were all published in a high impact factor journal (i.e. Lancet). This was expected because it is known in literature that papers published in journals with a high $I F$ would probably have high citations (Chuang \& Ho, 2015). Furthermore, the article titled "Impact of permethrin impregnated bednets on child mortality in Kassena-Nankana district, Ghana: A randomized controlled trial" (Binka et al., 1996) was the most frequently cited article with $T C_{2015}$ of 260 by F.N. Binka from Navrongo Health Research Centre as the first and also corresponding authors.

In conclusion, Ghanaian researchers/lecturers should publish their scientific works in high impact factor journals captured by Thomson Reuters to have high citations.

\section{RESUMEN}

Análisis bibliométrico de las publicaciones de Ghana en el Índice de Citación de Ciencia. Ghana es un país del oeste de África para el cual aparentemente hay limitados estudios cienciométricos. El objetivo de este estudio fue analizar la contribución de Ghana al conocimiento capturado en la base de datos del Índice de Citación Expandido de Ciencia Thomson Reuters (SCIEXPANDED) de 1936-2016. Se analizaron los siguientes datos: tipo de documento, lenguaje de la publicación, tendencia de la publicación, categorías temáticas de Web of Science, revistas, colaboración internacional, instituciones, autores y artículos frecuentemente citados. Los indicadores como el número total de artículos, artículos de primer autor y artículos de autor de correspondencia se aplicaron para comparar el rendimiento de publicación de países e instituciones colaboradoras. También la cantidad de artículos de una institución: la cantidad de artículos de colaboración nacional: la cantidad de artículos de colaboración internacional (S:N:I) se utilizaron para comparar las características de publicación de las instituciones de Ghana. Los resultados muestran que la tendencia de publicación incrementó de 1998 al 2015 con investigaciones enfocadas en salud y medicina. PLoS One fue la revista más productiva y el país más colaborador para los artículos de Ghana fue EE.UU. Las contribuciones de la Universidad de Ghana se clasificaron como los mejores artículos de Ghana y los artículos con mayores citaciones fueron los de colaboración internacional. En conclusión, la distribución del conocimiento de autores Ghaneses es masiva en las áreas público, ambiental y salud ocupacional y medicina tropical pero el factor de impacto es más alto en artículos de inmunología, enfermedades infecciosas y microbiología. Por lo tanto, los autores Ghaneses están alentados a publicar más artículos en revistas de alto factor de impacto con el Índice de Citación Expandido de Ciencia Thomson Reuters para que sus publicaciones sean reconocidas por las bases de datos internacionales existentes.

Palabras clave: Ghana; SCI-EXPANDED; Web of Science; tendencias de investigación; colaboraciones

\section{REFERENCES}

Agnandji, S. T., Lell, B., Fernandes, J. F., Abossolo, B. P., Methogo, B., Kabwende, A. L., ... Vansadia, P. (2012). A phase 3 trial of RTS, S/AS01 malaria vaccine in African infants. The New England Journal of Medicine, 367(24), 2284-2295. doi: 10.1056/ NEJMoa 1208394 
Agyeman, E. A., \& Bilson, A. (2015). Research focus and trends in nuclear science and technology in Ghana: a bibliometric study based on the INIS database. Library Philosophy and Practice (e-journal). Paper 1212

Alemna, A. (2016). Scholarly Publishing in Africa and the role of the Open Access Initiative (OAI). Retrieved from http: //hdl.handle.net/123456789/8508

Aswathy, S., \& Gopikuttan, A. (2013). Productivity pattern of universities in Kerala: a scientometric analysis. Annals of Library and Information Studies (ALIS), 60(3), 176-185.

Attafuah, A., \& Tinsley, T. (1958). Virus diseases of Adansonia digitata L. (Bombacaceae) and their relation to cacao in Ghana. Annals of Applied Biology, 46(1), 20-22.

Atuahene, F. (2011). Re-thinking the missing mission of higher education: an anatomy of the research challenge of African universities. Journal of Asian and African Studies, 46(4), 321-341.

Bhatt, S., Gething, P. W., Brady, O. J., Messina, J. P., Farlow, A. W., Moyes, C. L., ... Sankoh, O. (2013). The global distribution and burden of dengue. Nature, 496(7446), 504-507.

Binka, F.N., Kubaje, A., Adjuik, M., Williams, L.A., Lengeler, C., Maude, G.H., ... Smith, P.G. (1996). Impact of permethrin impregnated bednets on child mortality in Kassena-Nankana district, Ghana: a randomized controlled trial. Tropical Medicine \& International Health, 1(2), 147-154.

Boshoff, N. (2009). Neo-colonialism and research collaboration in Central Africa. Scientometrics, 81(2), 413-434.

Boshoff, N. (2010). South-South research collaboration of countries in the Southern African Development Community (SADC). Scientometrics, 84(2), 481-503.

Bousquet, J., Khaltaev, N., Cruz, A., Denburg, J., Fokkens, W., Togias, A., ... Van Weel, C. (2008). Allergic rhinitis and its impact on asthma (ARIA) 2008. Allergy, 63(s86), 8-160.

Carpenter, S. R., Mooney, H. A., Agard, J., Capistrano, D., DeFries, R. S., Díaz, S., ... Pereira, H.M. (2009). Science for managing ecosystem services: beyond the millennium ecosystem assessment. Proceedings of the National Academy of Sciences, 106(5), 1305-1312.

Chuang, K. Y., Chuang, Y. C., Ho, M., \& Ho, Y. S. (2011). Bibliometric analysis of public health research in Africa: the overall trend and regional comparisons. South African Journal of Science, 107(5-6), 54-59.

Chuang, K. Y., \& Ho, Y. S. (2015). An evaluation based on highly cited publications in Taiwan. Current Science, 108(5), 933-941.
Chuang, K. Y., Olaiya, M. U., \& Ho, Y. S. (2012) Bibliometric analysis of the Polish Journal of Environmental Studies (2000-11). Polish Journal of Environmental Studies, 21(5), 1175-1183.

Chuang, K. Y., Wang, M. H., \& Ho, Y. S. (2011). Highimpact papers presented in the subject category of water resources in the essential science indicators database of the institute for scientific information. Scientometrics, 87(3), 551-562.

Fakhree, M. A. A., \& Jouyban, A. (2011). Scientometric analysis of the major Iranian medical universities Scientometrics, 87(1), 205-220.

Garfield, E. (2006). Citation indexes for science. A new dimension in documentation through association of ideas. International Journal of Epidemiology, 35(5), 1123-1127.

Garfield, E. (2007). The evolution of the science citation index. International Microbiology: Official Journal of the Spanish Society for Microbiology, 10(1), 65-70.

Garfield, E. (2009). The evolution of the science citation index. Contributions to Science, 5(1), 63-70.

Guerin, P. J., Olliaro, P., Nosten, F., Druilhe, P., Laxminarayan, R., Binka, F., ... White, N. J. (2002). Malaria: current status of control, diagnosis, treatment, and a proposed agenda for research and development. Lancet Infectious Diseases, 2(9), 564-573.

Ho, Y. S. (2007). Bibliometric analysis of adsorption technology in environmental science. Journal of Environmental Protection Science, 1(1), 1-11.

Ho, Y. S. (2012). Top-cited articles in chemical engineering in Science Citation Index Expanded: a bibliometric analysis. Chinese Journal of Chemical Engineering, 20(3), 478-488.

Ho, Y. S. (2013). The top-cited research works in the Science Citation Index Expanded. Scientometrics, 94(3), 1297-1312.

Ho, Y. S., \& Fu, H. Z. (2016). Mapping of metal-organic frameworks publications: a bibliometric analysis. Inorganic Chemistry Communications, 73, 174-182.

Ho, H. C., \& Ho, Y. S. (2015). Publications in dance field in Arts and Humanities Citation Index: a bibliometric analysis. Scientometrics, 105(2), 1031-1040.

Ho, Y. S., Satoh, H., \& Lin, S. Y. (2010). Japanese lung cancer research trends and performance in Science Citation Index. Internal Medicine, 49(20), 2219-2228.

Knight, R., \& Tinsley, T. (1958). Some histological observations on virus-infected Theobroma Cacao L. Annals of Applied Biology, 46(1), 7-10. 
Lewis, S. L., Lopez-Gonzalez, G., Sonké, B., AffumBaffoe, K., Baker, T. R., Ojo, L. O., ... Comiskey, J. A. (2009). Increasing carbon storage in intact African tropical forests. Nature, 457(7232), 1003-1006.

Li, Z., \& Ho, Y. S. (2008). Use of citation per publication as an indicator to evaluate contingent valuation research. Scientometrics, 75(1), 97-110.

Lomatey, I. T., Abledu, G. K., Baayel, P., Akussah, M., \& Botchway, H. K. (2016). A scientometric analysis of research performance of Ghanaian polytechnics. International Journal of Modern Education Research, 3(5), 37-40.

Lozano, R., Naghavi, M., Foreman, K., Lim, S., Shibuya, K., Aboyans, V., ... Murray, C. J. (2012). Global and regional mortality from 235 causes of death for 20 age groups in 1990 and 2010: a systematic analysis for the Global Burden of Disease Study 2010. Lancet, 380(9859), 2095-2128. doi: 10.1016/ S0140-6736(12)61728-0

Milojević, S., \& Leydesdorff, L. (2013). Information metrics (iMetrics): a research specialty with a sociocognitive identity? Scientometrics, 95(1), 141-157.

Monge-Nájera, J., \& Ho, Y. S. (2012). Costa Rica Publications in the Science Citation Index Expanded: a bibliometric analysis for 1981-2010. Revista de Biología Tropical, 60(4), 1649-1661.

Monge-Nájera, J., \& Ho, Y. S. (2015). Bibliometry of Panama publications in the Science Citation Index Expanded: publication type, language, fields, authors and institutions. Revista de Biología Tropical, 63(4), $1255-1266$

Monge-Nájera, J., \& Ho, Y. S. (2017a). Bibliometrics of Nicaraguan publications in the Science Citation Index Expanded. Revista de Biología Tropical, 65(2), 643-655.

Monge-Nájera, J., \& Ho, Y. S. (2017b). Bibliometrics of Honduras publications in the Science Citation Index Expanded. Revista de Biología Tropical, 6(2), 657-658.

Murray, C. J., Vos, T., Lozano, R., Naghavi, M., Flaxman, A. D., Michaud, C., ... Lopez, A. D. (2012). Disability-adjusted life years (DALYs) for 291 diseases and injuries in 21 regions, 1990-2010: a systematic analysis for the Global Burden of Disease Study 2010. Lancet, 380(9859), 2197-2223. doi: 10.1016/ S0140-6736(12)61689-4

Muzha, I., Filipi, N., Lede, R., Copertari, P., Traverso, C., Copertari, A., ... Olldashi, F. (2004). Effect of intravenous corticosteroids on death within 14 days in 10008 adults with clinically significant head injury (MRC CRASH trial): Randomised placebo-controlled trial. Lancet, 364(9442), 1321-1328.

Ng, M., Fleming, T., Robinson, M., Thomson, B., Graetz, N., Margono, C., ... Abera, S. F. (2014). Global, regional, and national prevalence of overweight and obesity in children and adults during 1980-2013: a systematic analysis for the Global Burden of Disease Study 2013. Lancet, 384 (9945), 766-781.

Noruzi, A., \& Abdekhoda, M. (2014). Scientometric analysis of Iraqi-Kurdistan universities' scientific productivity. Electronic Library, 32(6), 770-785.

Nwagwu, W., \& Egbon, O. (2011), Bibliometric analysis of Nigeria's social science and arts and humanities publications in Thomson Scientific databases. Electronic Library, 29(4), 438-456.

Owusu-Nimo, F., \& Boshoff, N. (2017). Research collaboration in Ghana: patterns, motives and roles. Scientometrics, 110(3), 1099-1121.

Pouris, A. (2010). A scientometric assessment of the Southern Africa Development Community: science in the tip of Africa. Scientometrics, 85(1), 145-154.

Pouris, A., \& Pouris, A. (2009). The state of science and technology in Africa (2000-2004). Scientometrics, 79(2), 297-309.

Sam, J. (2008). An Analysis of Ghana Library Journal: A Bibliometric Study. African Journal of Library Archives and Information Science, 18(1), 55-62.

Smith, M. W., Patterson, N., Lautenberger, J. A., Truelove, A. L., McDonald, G. J., Waliszewska, A., ... Le, E. (2004). A high-density admixture map for disease gene discovery in African Americans. The American Journal of Human Genetics, 74(5), 1001-1013.

Stewart, J. M. (1967). Tongue root position in Akan vowel harmony. Phonetica, 16(4), 185-204.

Tijssen, R. J. (2007). Africa's contribution to the worldwide research literature: new analytical perspectives, trends, and performance indicators. Scientometrics, 71(2), 303-327.

Tinsley, T., \& Wharton, A. (1958). Studies on the host ranges of viruses from Theobroma cacao L. Annals of Applied Biology, 46(1), 1-6.

Toivanen, H., \& Ponomariov, B. (2011). African regional innovation systems: bibliometric analysis of research 
collaboration patterns 2005-2009. Scientometrics, 88(2), 471-493.

Vos, T., Flaxman, A. D., Naghavi, M., Lozano, R., Michaud, C., Ezzati, M., ... Murray, C. J. (2012). Years lived with disability (YLDs) for 1160 sequelae of 289 diseases and injuries 1990-2010: a systematic analysis for the Global Burden of Disease Study 2010. Lancet, 380(9859), 2163-2196. doi: 10.1016/ S0140-6736(12)61729-2

Wambu, E. W., \& Ho, Y. S. (2016). A bibliometric analysis of drinking water research in Africa. Water $S A$, 42(4), 612-620.
Wang, M. H., Fu, H. Z., \& Ho, Y. S. (2011). Comparison of universities' scientific performance using bibliometric indicators. Malaysian Journal of Library and Information Science, 16(2), 1-19.

Wang, M. H., Yu, T. C., \& Ho, Y. S. (2010). A bibliometric analysis of the performance of Water Research. Scientometrics, 84(3), 813-820.

Zavala, F., Tam, J. P., Hollingdale, M. R., Cochrane, A. H., Quakyi, I., Nussenzweig, R. S., \& Nussenzweig, V. (1985). Rationale for development of a synthetic vaccine against Plasmodium falciparum malaria. Science, 228(4706), 1436-1440. 